\title{
Retraction Note to: Comment on an article: "Osteoporosis in the age of COVID-19 patients"
}

\author{
O. Ć. Ibrahimagić ${ }^{1} \cdot$ A. Vujadinović ${ }^{2} \cdot$ Z. Ercegović $^{3} \cdot$ S. Kunić ${ }^{4}$ (I) $\cdot$ Dž. Smajlović ${ }^{1} \cdot$ Z. Dostović $^{1}$
}

Published online: 14 July 2021

(C) International Osteoporosis Foundation and National Osteoporosis Foundation 2021

\section{Retraction Note to: Osteoporosis International (2021) 32:783-784}

https://doi.org/10.1007/s00198-020-05607-6

The Editors-in Chief have retracted this Letter to the Editor. The Letter presents the same hypothesis relating to B-vitamins in the treatment of COVID-19 as a previous Letter to the Editor by the same author group in another journal [1]. The Editors-in-Chief therefore consider this Letter to be redundant. The authors disagree with this retraction.

The online version of the original article can be found at https://doi.org/ 10.1007/s00198-020-05607-6

\section{S. Kunić}

suljo.kunic@hotmail.com

1 Department of Neurology, University Clinical Centre Tuzla, 75000 Tuzla, Bosnia and Herzegovina

2 Department of Orthopaedics and Traumatology, University Clinical Centre Tuzla, 75000 Tuzla, Bosnia and Herzegovina

3 Department of Neurosurgery, University Clinical Centre Tuzla, 75000 Tuzla, Bosnia and Herzegovina

4 Present address: Department of Neurology, Primary Health Care Centre Tuzla, Albina i Franje Herljevića 1, 75000 Tuzla, Bosnia and Herzegovina

\section{Reference}

1. Omer Ć (2020) Ibrahimagić, Zlatko Ercegović, Aleksandar Vujadinović \& Suljo Kunić. Medications in COVID-19 patients: summarizing the current literature from an orthopaedic perspective. International Orthopaedics (SICOT) 44:2811-2812

Publisher's note Springer Nature remains neutral with regard to jurisdictional claims in published maps and institutional affiliations. 